\title{
Elevated red cell distribution width predicts poor outcome in young patients with community acquired pneumonia
}

Eyal Braun ${ }^{1,2 \dagger}$, Erel Domany ${ }^{2 \dagger}$, Yael Kenig ${ }^{1}$, Yoav Mazor ${ }^{1,2}$, Badira F Makhoul ${ }^{1,2}$ and Zaher S Azzam ${ }^{1,2,3^{*}}$

\begin{abstract}
Introduction: Community acquired pneumonia (CAP) is a major cause of morbidity and mortality. While there is much data about risk factors for severe outcome in the general population, there is less focus on younger group of patients. Therefore, we aimed to detect simple prognostic factors for severe morbidity and mortality in young patients with CAP.
\end{abstract}

Methods: Patients of 60 years old or younger, who were diagnosed with CAP (defined as pneumonia identified 48 hours or less from hospitalization) between March 1, 2005 and December 31, 2008 were retrospectively analyzed for risk factors for complicated hospitalization and 90-day mortality.

Results: The cohort included 637 patients. 90-day mortality rate was 6.6\% and the median length of stay was 5 days. In univariate analysis, male patients and those with co-morbid conditions tended to have complicated disease. In multivariate analysis, variables associated with complicated hospitalization included post chest radiation state, prior neurologic damage, blood urea nitrogen $(B U N)>10.7 \mathrm{mmol} / \mathrm{L}$ and red cell distribution width (RDW) > 14.5\%; whereas, variables associated with an increased risk of 90-day mortality included age $\geq 51$ years, prior neurologic damage, immunosuppression, and the combination of abnormal white blood cells (WBC) and elevated RDW. Complicated hospitalization and mortality rate were significantly higher among patients with increased RDW regardless of the white blood cell count. Elevated RDW was associated with a significant increase in complicated hospitalization and 90-day mortality rates irrespective to hemoglobin levels.

Conclusions: In young patients with CAP, elevated RDW levels are associated with significantly higher rates of mortality and severe morbidity. RDW as a prognostic marker was unrelated with hemoglobin levels.

Trial registration: ClinicalTrials.Gov NCT00845312

Keywords: Pneumonia, Red Blood Cell Width, Mortality, Prognosis, Complicated Hospitalization

\section{Introduction}

Community acquired pneumonia (CAP) is a major cause of severe morbidity and mortality. It is the sixth most common cause of death in the USA, and it is estimated that four million cases of CAP occur annually [1]. There is a worldwide increase in the number of hospitalizations due to CAP in the general population [2-4].

\footnotetext{
* Correspondence: z_azzam@rambam.health.gov.il

+ Contributed equally

'Department of Internal Medicine B, Rambam Health Care Campus, 1

Ha'aliya St. P.O.B. 9602 Bat Galim, Haifa 31096, Israel

Full list of author information is available at the end of the article
}

Much research has been conducted in recent decades to determine prognostic factors for adverse outcome in patients hospitalized for CAP, including concomitant diseases and laboratory parameters on admission [5]. Several prognostic scores were developed based upon these characteristics, such as the Pneumonia Patient Outcomes Research Team score [6]. Ghanem-Zoubi et al reported recently in a study that included $43 \%$ of patients with pneumonia that simple clinical score and mortality in emergency department sepsis scores were the most appropriate clinical scores to predict the mortality of patients with sepsis in general internal medicine departments [7]. Although there is a large body of

\section{() Biomed Central}

(c) 2011 Braun et al.; licensee BioMed Central Ltd This is an open access article distributed under the terms of the Creative Commons Attribution License (http://creativecommons.org/licenses/by/2.0), which permits unrestricted use, distribution, and reproduction in any medium, provided the original work is properly cited 
evidence in this field in the general population, less focus was put in younger group of patients, even though several recent studies showed that there is an increasing number of hospital admissions due to CAP among patients less than 60 years old [8]. Recently, it was reported that procalcitonin is associated with the severity of illness in patients with severe pneumonia and appears to be a prognostic marker of morbidity and mortality [9].

Red Blood Cell Distribution Width (RDW) is a laboratory index used in the differential diagnosis of microcytic anemia. Recently, several studies showed that a high RDW index predicts severe morbidity and mortality in various cardiac conditions, such as acute and chronic congestive heart failure $[10,11]$, pulmonary hypertension, [12] and stroke. [13]

Therefore, our primary aim was to determine prognostic factors that are associated with complicated hospitalization and 90-day mortality. The major secondary endpoint was to assess whether RDW is associated with adverse outcome irrespective of hemoglobin and white blood cell (WBC) levels.

\section{Materials and methods}

Patients 60 years old or younger, who were diagnosed with CAP (defined as pneumonia identified 48 hours or less from hospitalization) between 1 March, 2005 and 31 December, 2008 were retrospectively analyzed for risk factors for severe morbidity or mortality. Data were collected from the Prometheus, Rambam Integrated Computer System for handling patients' medical records, and the 90-day mortality data were retrieved from the database of our hospital and the ministry of health.

Complicated hospitalization was defined as at least one of the following parameters: hospitalization longer than 10 days, admission to ICU and in- hospital mortality. Otherwise, the hospitalization was defined as uncomplicated. The Rambam Hospital Institutional Review Board approved the study. The need for informed consent was waived.

Exclusion criteria included transfer from another hospital, hospitalization for any cause other than CAP during the 30 days prior to admission, hospital-acquired pneumonia (defined as pneumonia which was diagnosed more than 48 hours after admission) or partial antibiotic treatment before admission.

The following data were retrieved from the electronic medical records of the patients:

(1) Malignancies: solid tumors, hematologic malignancies. (2) Pulmonary diseases: bronchial asthma, chronic obstructive lung disease, interstitial lung disease, bronchiectasis, permanent tracheostomy, lung malignancy, past history of thoracic radiotherapy, previous episode of pneumonia, and previous or current active smoker. (3) Immune suppression conditions: current chronic corticosteroid treatment, current or recent chemotherapy treatment, carrier of HIV, primary immune deficiency, history of bone marrow transplantation. (4) Cardiovascular diseases. (5) Chronic kidney disease. (6) Diabetes mellitus. (7) Liver cirrhosis. (8) Prior neurologic damage. (9) Chronic alcohol use. (10) Intravenous drug abuse. (11) Nursing house residents.

\section{Laboratory variables on admission}

Serum glucose, creatinine, sodium, hemoglobin, WBC, RDW and blood urea nitrogen (BUN) were measured on admission.

Hemoglobin levels, mean corpuscular volume and RDW were measured on admission and prior to hospital discharge, using the Advia 120 Hematology Analyzer (Siemens Healthcare Diagnostics Deerfield, Illinois, USA). Glucose, BUN and creatinine levels were measured using the "Dimension" (Siemens Healthcare Diagnostics Deerfield, Illinois, USA).

RDW is reported as coefficient of variation (in percent) of red blood cell volume. The normal range for RDW in our laboratory is 11.5 to $14.5 \%$. The correctness of this normal range was confirmed by analyzing RDW data in 17,293 ambulatory subjects who attended the Rambam Center for Preventive Medicine for a medical examination and health counseling. In this group, mean RDW was $13.1 \%$ (median $13.0 \%$ ) with 95\% confidence interval (CI) of RDW of 12.0 to $14.4 \%$.

\section{Statistical analysis}

Binary logistic regression analysis was used for the calculation of the odds ratios (OR) with 95\% CI and $P$ values in univariate analysis to identify association between patient characteristic and 90-day mortality and complicated hospitalization. Multivariate forward stepwise logistic regression was performed to assess the relation between patient characteristics: co-morbidities, laboratory results, and 90-day mortality or complicated hospitalizations.

Variables were selected as candidates for the multivariate analysis on the basis of the level of significance of the univariate association with 90-day mortality and complicated hospitalization $(P<0.1)$. Notably, there was no predilection in choosing RDW or any other variable in the statistical model.

The area under curve (AUC) was used as a measure of model of discrimination. The calibration of the prediction equation was assessed by comparing the observed and expected numbers of 90-day mortality or complicated hospitalization. The calibration of the prediction equation was assessed by comparing the observed and expected numbers of 90-day mortality or complicated hospitalization rate by decile of predicted risk. The Hosmer-Lemeshow goodness-of-fit statistic was calculated. 
Comparing of patients characteristics from two groups (complicated and uncomplicated) was done by using chi-square test. Student's t-test was used to compare age between the two groups, whereas, length of stay was compared using Mann-Whitney nonparametric test.

Two-tailed $P$ values of 0.05 or less were considered as statistically significant. All statistical analyses were performed using SPSS (Statistics Products Solutions Services; Armonk, New York, USA) 17.0 software for Windows; Redmond, Washington, USA.

\section{Results}

The cohort included 637 patients; $63 \%$ were males, median age was 46 years, the in-hospital mortality rate was $6.6 \%$ and the median length of stay was five days.

\section{Univariate analysis of complicated hospitalizations and 90-day mortality}

As shown in Table 1, 171 patients (26\%) experienced complicated hospitalization; male patients and those with co-morbid conditions tended to have a complicated disease. Notably, patients who had concomitant diabetes mellitus, chronic liver diseases, interstitial lung diseases and past chemotherapy did not have a more complicated course of CAP ( $P=$ not significant).

As depicted in Table 1, patients who had disturbed renal function tests, anemia, abnormal WBC and elevated RDW on admission had a complicated hospitalization.

The median length of stay was 4 and 12 days in uncomplicated and complicated patients, respectively. In

Table 1 Baseline characteristics of the cohort with univariate analysis of risk factors for detection of complicated hospitalization

\begin{tabular}{|c|c|c|c|c|c|c|}
\hline \multicolumn{2}{|l|}{ Characteristic } & \multirow{2}{*}{$\begin{array}{l}\mathrm{N}_{\mathrm{T}}(\%) \\
637\end{array}$} & \multirow{2}{*}{$\frac{\mathrm{N}_{\text {UC }}(\%)}{466(73.2)}$} & \multirow{2}{*}{$\frac{\mathbf{N}_{\mathbf{C}}(\%)}{171(26.8)}$} & \multirow[t]{2}{*}{ Odds ratio $(95 \% \mathrm{Cl})$} & \multirow[t]{2}{*}{$P$ value } \\
\hline & & & & & & \\
\hline \multirow[t]{2}{*}{ Gender } & Male & $403(63.3)$ & $282(60.5)$ & $121(70.8)$ & $1.58(1.082-2.305)$ & 0.018 \\
\hline & Female & $234(36.7)$ & $184(39.5)$ & $50(29.2)$ & Reference & 1.000 \\
\hline \multirow[t]{4}{*}{ Age (years) } & $\leq 30$ & $126(19.8)$ & $106(27)$ & $20(11.7)$ & Reference & \\
\hline & $31-40$ & $136(21.4)$ & $97(29.2)$ & $39(22.8)$ & $2.13(1.163-3.904)$ & 0.014 \\
\hline & $41-50$ & $144(22.6)$ & 109 (30.9) & $35(20.5)$ & $1.70(0.924-3.135)$ & 0.088 \\
\hline & $51-60$ & $231(36.3)$ & $154(49.6)$ & $77(45.0)$ & $2.65(1.528-4.596)$ & 0.001 \\
\hline \multicolumn{7}{|c|}{ Co-morbid conditions } \\
\hline \multicolumn{2}{|l|}{ Malignancy } & $60(9.4 \%)$ & $32(6.9)$ & $28(16.4)$ & $2.66(1.546-4.563)$ & $<0.0001$ \\
\hline \multicolumn{2}{|c|}{ Prior neurologic damage } & $125(19.6 \%)$ & $57(12.2)$ & $68(39.8)$ & $4.74(3.134-7.160)$ & $<0.0001$ \\
\hline \multicolumn{2}{|c|}{ Chronic renal failure } & $26(4.1 \%)$ & $15(3.2)$ & $11(6.4)$ & $2.07(0.930-4.594)$ & 0.075 \\
\hline \multicolumn{2}{|l|}{ Heart disease } & $56(8.8 \%)$ & $34(7.3)$ & $22(12.9)$ & $1.88(1.063-3.310)$ & 0.030 \\
\hline \multicolumn{2}{|l|}{ Lung disease ${ }^{*}$} & 193 (30.3\%) & $128(27.5)$ & $65(38)$ & $1.61(1.115-2.337)$ & 0.011 \\
\hline \multicolumn{2}{|l|}{ Asthma } & $41(6.4 \%)$ & $35(7.5)$ & $6(3.5)$ & $0.45(0.185-1.084)$ & 0.075 \\
\hline \multicolumn{2}{|c|}{ Chronic obstructive lung disease } & $77(12.1 \%)$ & $50(10.7)$ & $27(15.8)$ & $1.56(0.941-2.585)$ & 0.084 \\
\hline \multicolumn{2}{|c|}{ Lung malignancy } & $37(5.8 \%)$ & $20(4.3)$ & $17(9.9)$ & $2.46(1.257-4.820)$ & 0.009 \\
\hline \multicolumn{2}{|c|}{ Post chest radiation } & $31(4.9 \%)$ & $14(3)$ & $17(9.9)$ & $2.96(1.074-8.146)$ & 0.036 \\
\hline \multicolumn{2}{|c|}{ Immune deficiency } & $156(24.5 \%)$ & 98 )21) & $58(33.9)$ & $1.93(1.309-2.839)$ & 0.001 \\
\hline \multicolumn{2}{|c|}{ Hematologic malignancy } & $45(7.1 \%)$ & $30(6.4)$ & $15(8.8)$ & $2.38(0.944-5.982)$ & 0.066 \\
\hline \multicolumn{2}{|c|}{ Corticosteroid therapy } & $76(11.9 \%)$ & $44(9.4)$ & $32(18.7)$ & $2.21(1.347-3.619)$ & 0.002 \\
\hline \multicolumn{2}{|c|}{ Nursing institution } & $52(8.2 \%)$ & $21(4.5)$ & $31(18.1)$ & $4.69(2.612-8.427)$ & $<0.0001$ \\
\hline \multicolumn{2}{|c|}{ SBP on admission (mmHg) } & $137.3 \pm 32.1$ & $137.9 \pm 36.1$ & $136.6 \pm 29.0$ & 1.009 (0.942-1.082) & NS \\
\hline \multicolumn{2}{|c|}{ DBP on admission $(\mathrm{mmHg})$} & $77.4 \pm 16.1$ & $77.8 \pm 18.3$ & $76.9 \pm 12.6$ & $1.011(0.945-1.081)$ & NS \\
\hline \multicolumn{2}{|c|}{ Heart rate on admission $\left(\min ^{-1}\right)$} & $86.7 \pm 20.2$ & $86.8 \pm 20.6$ & $86.7 \pm 20.1$ & $0.998(0.926-1.077)$ & NS \\
\hline \multicolumn{7}{|c|}{ Laboratory parameters } \\
\hline \multicolumn{2}{|c|}{$\mathrm{BUN}>10.7 \mathrm{mmol} / \mathrm{L}$} & $65(10.2 \%)$ & $35(7.5)$ & $30(17.5)$ & $2.62(1.552-4.422)$ & $<0.0001$ \\
\hline \multicolumn{2}{|c|}{ Creatinine $>114 \mu \mathrm{mol} / \mathrm{L}$} & $88(13.8 \%)$ & $54(11.6)$ & $34(19.9)$ & $1.89(1.183-3.031)$ & 0.008 \\
\hline \multicolumn{2}{|c|}{ Hemoglobin <110 g/L } & $113(17.7 \%)$ & $68(14.6)$ & $45(26.3)$ & $2.11(1.375-3.229)$ & 0.001 \\
\hline Hematocrit $<3$ & & $56(8.8 \%)$ & $31(6.7)$ & $25(14.6)$ & $2.42(1.383-4.233)$ & 0.002 \\
\hline Glucose $>13.8$ & & $39(6.1 \%)$ & $24(5.2)$ & $15(8.8 \%)$ & $1.77(0.903-3.454)$ & 0.096 \\
\hline$W B C<4$ or $>1$ & & $347(54.5 \%)$ & $238(51.1)$ & $109(63.7)$ & $1.68(1.174-2.416)$ & 0.005 \\
\hline RDW >14.5\% & & $218(34.2 \%)$ & $123(26.4)$ & $95(55.6)$ & 3.49 (2.419-5.023) & $<0.0001$ \\
\hline
\end{tabular}

$P<0.05$ represents significant statistical difference between patients with complicated and uncomplicated hospitalization

BUN, blood urea nitrogen; $\mathrm{Cl}$, confidence interval; DBP, diastolic blood pressure; $\mathrm{N}_{\mathrm{C}}$, number of complicated admissions; ns, not significant; $\mathrm{N}_{\mathrm{T}}$, all the patients that were included in the cohort; $\mathrm{N}_{U C}$, number of uncomplicated admissions as defined; RDW, red cell width distribution; SBP, systolic blood pressure; WBC, white blood cells.

* Includes bronchial asthma, chronic obstructive lung disease, interstitial lung disease, bronchiectasis, permanent tracheostomy, lung malignancy, past history of thoracic radiotherapy, previous episode of pneumonia, and previous or current active smoking. 
Table 2 The combination of elevated RDW and abnormal WBC count had the highest odds ratio for complicated hospitalization

\begin{tabular}{llllll}
\hline & & n (\%) & Complicated hospitalization (\%) & Odds ratio (95\% Cl) & $P$ value \\
\hline \multirow{2}{*}{ RDW $\leq 14.5$} & $4 \leq \mathrm{WBC} \leq 12 \times 10^{9} / \mathrm{L}$ & $197(30.9)$ & $15.7 \%$ & & Reference \\
& $\mathrm{WBC}<4$ or $>12 \times 10^{9} / \mathrm{L}$ & $222(34.9)$ & $20.3 \%$ & $1.36(0.82-2.25)$ & 0.23 \\
$\mathrm{RDW}>14$. & $4 \leq \mathrm{WBC} \leq 12 \times 10^{9} / \mathrm{L}$ & $93(14.6)$ & $33.3 \%$ & $2.68(1.5-4.77)$ & 0.001 \\
& $\mathrm{WBC}<4$ or $>12 \times 10^{9} / \mathrm{L}$ & $125(19.6$ & $51.2 \%$ & $5.62(3.34-9.45)$ & $<0.0001$ \\
\hline
\end{tabular}

$\mathrm{Cl}$, confidence interval; OR, odds ratio; RDW, red cell width distribution; WBC, white blood cells.

patients who had a complicated course of pneumonia, 90-day mortality was $31 \%$ as compared with $3.9 \%$ in uncomplicated patients $(P<0.03)$. Notably, the combination of elevated RDW and abnormal WBC count had the highest OR for complicated hospitalization and 90-day mortality (Tables 2 and 3 respectively). We found a statistically significant association between each element of the complicated hospitalization and elevated RDW. For length of stay of more than 10 days, linear regression showed B $=3.5$ (95\% CI $=1.8-5.1, P<0.0001)$. For ICU admission logistic regression showed OR of 1.97 (95\% CI $=1.2-3.1, P=0.004)$, and for in- hospital mortality, binary regression showed OR of $3.5(95 \% \mathrm{CI}=2.4-5)$.

\section{Multivariate analysis of complicated hospitalizations}

All variables that were associated $(P<0.1)$ with complicated hospitalization were included in the initial multivariate prediction rule. Results of multivariate analysis are presented in Table 4.

In a model that does not include RDW, variables that were associated with complicated hospitalization included prior neurologic damage, heard disease, prior corticosteroid treatment; post chest radiation state, BUN above $10.7 \mathrm{mmol} / \mathrm{L}$ and abnormal WBC.

Whenever RDW was included in the model, the variables that were associated with complicated hospitalization included prior neurologic damage, post chest radiation, BUN above $10.7 \mathrm{mmol} / \mathrm{L}$ and RDW above $14.5 \%$. However, with the inclusion of both elevated RDW and abnormal WBC, the variables that were linked with complicated hospitalization included prior neurologic damage; post chest radiation BUN above $10.7 \mathrm{mmol} / \mathrm{L}$ and combination of elevated RDW and abnormal WBC. A model with RDW improved $\mathrm{AUC}_{\mathrm{ROC}}$ as compared with a model without RDW from 0.736 (95\% CI $=0.691-0.781)$ to $0.743(95 \% \mathrm{CI}=0.699-0.788)$; conceivably, the improvement was prominent in a model with the combination of RDW and abnormal WBC from 0.736 to 0.755 (95\% CI $=0.711-0.799)$. The Hosmer-Lemeshev goodness-of-fit statistic across decile of risk was not statistically significant indicating little departure a perfect fit in all three models.

\section{Multivariate analysis of 90-day mortality}

All variables that were found to be associated $(P<0.1)$ with 90-day mortality in the univariate analysis (Table 5 ); were included in the initial multivariate prediction rule. As depicted in Table 6; in the first model that excluded RDW, variables that were associated with an increased risk of 90-day mortality included age 51 years or older, prior neurologic damage and immunosupression. Including RDW in the model demonstrated that the same variables in addition to elevated RDW were associated with increased 90-day mortality. Notably, the model that joined both elevated RDW and abnormal WBC; it was proved that this combination is significantly associated with increased mortality in addition to the three previous variables. The model with RDW improved $\mathrm{AUC}_{\mathrm{ROC}}$ as compared with a model without RDW from 0.807 (95\% CI $=0.746-0.868)$ to 0.822 (95\% $\mathrm{CI}=0.766-0.879)$; while the model of combined elevated RDW and abnormal WBC improved $\mathrm{AUC}_{\mathrm{ROC}}$ from 0.807 to 0.828 (95\% CI $=0.772-0.885)$. The HosmerLemeshev goodness-of-fit statistic across decile of risk was not statistically significant, indicating little departure from a perfect fit in all three models.

Table 3 The combination of elevated RDW and abnormal WBC count disclosed the highest OR for 90-day mortality

\begin{tabular}{llllll}
\hline & & $\mathbf{n ~ ( \% )}$ & 90-day mortality (\%) & Odds ratio (95\% Cl) & $\boldsymbol{P}$ value \\
\hline \multirow{2}{*}{ RDW $\leq 14.5$} & $4 \leq \mathrm{WBC} \leq 12 \times 10^{9} / \mathrm{L}$ & 637 & & & \\
& $\mathrm{WBC}<4$ or $>12 \times 10^{9} / \mathrm{L}$ & $222(34.9)$ & $5.0 \%$ & Reference & \\
& $\mathrm{RDW}>14$. & $93(14.6)$ & $8.6 \%$ & $2.5(0.8-8.0)$ & 0.119 \\
& $4 \leq \mathrm{WBC} \leq 12 \times 10^{9} / \mathrm{L}$ & $125(19.6$ & $15.2 \%$ & $8.5(1.3-15.5)$ & 0.016 \\
& $\mathrm{WBC}<4$ or $>12 \times 10^{9} / \mathrm{L}$ & $12.9-26.1)$ & $<0.0001$ \\
\hline
\end{tabular}

$\mathrm{Cl}$, confidence interval; $\mathrm{OR}$, odds ratio; $\mathrm{RDW}$, red cell width distribution; $\mathrm{WBC}$, white blood cells. 
Table 4 Results of multivariate analysis of risk factors for complicated hospitalization

\begin{tabular}{|c|c|c|c|c|c|c|c|c|c|c|c|c|c|c|c|c|}
\hline & \multirow{3}{*}{$\begin{array}{l}\% \text { from } \\
\text { Total }\end{array}$} & \multicolumn{5}{|c|}{ Without RDW } & \multicolumn{5}{|c|}{ With RDW } & \multicolumn{5}{|c|}{ RDW and abnormal WBC } \\
\hline & & \multirow[t]{2}{*}{ Coef. } & \multirow[t]{2}{*}{$\begin{array}{l}P \\
\text { value }\end{array}$} & \multirow[t]{2}{*}{$\begin{array}{l}\text { Adjusted odds } \\
\text { ratio }\end{array}$} & \multicolumn{2}{|c|}{$\begin{array}{l}95 \% \\
\text { confidence } \\
\text { interval }\end{array}$} & \multirow[t]{2}{*}{ Coef. } & \multirow[t]{2}{*}{$\begin{array}{l}P \\
\text { value }\end{array}$} & \multirow[t]{2}{*}{$\begin{array}{l}\text { Adjusted odds } \\
\text { ratio }\end{array}$} & \multicolumn{2}{|c|}{$\begin{array}{l}95 \% \\
\text { confidence } \\
\text { interval }\end{array}$} & \multirow[t]{2}{*}{ Coef. } & \multirow[t]{2}{*}{$\begin{array}{l}P \\
\text { value }\end{array}$} & \multirow[t]{2}{*}{$\begin{array}{l}\text { Adjusted odds } \\
\text { ratio }\end{array}$} & \multicolumn{2}{|c|}{$\begin{array}{l}95 \% \\
\text { confidence } \\
\text { interval }\end{array}$} \\
\hline & & & & & Lower & Upper & & & & Lower & Upper & & & & Lower & Upper \\
\hline Prior neurologic damage & 19.6 & 1.7 & $<0.0001$ & 5.3 & 3.4 & 8.2 & 1.5 & $<0.0001$ & 4.5 & 2.9 & 7.0 & 1.6 & $<0.0001$ & 4.7 & 3.0 & 7.3 \\
\hline Heart disease & 8.8 & 0.6 & 0.044 & 1.9 & 1.0 & 3.5 & & & & & & & & & & \\
\hline Corticosteroid therapy & 11.9 & 0.7 & 0.01 & 2 & 1.2 & 3.5 & & & & & & & & & & \\
\hline Post chest radiation & 4.9 & 1.4 & $<0.001$ & 4.1 & 1.9 & 8.9 & 1.1 & 0.006 & 3.1 & 1.4 & 6.9 & 1.1 & 0.007 & 3.0 & 1.4 & 6.8 \\
\hline $\mathrm{BUN}>10.7 \mathrm{mmol} / \mathrm{L}$ & 10.2 & 0.8 & 0.008 & 2.2 & 1.2 & 3.8 & 0.8 & 0.004 & 2.3 & 1.3 & 4.1 & 0.8 & 0.004 & 2.3 & 1.3 & 4.1 \\
\hline WBC $<4$ or $>12 \times 10^{9} / \mathrm{L}$ & 54.5 & 0.6 & 0.004 & 1.8 & 1.2 & 2.7 & & & & & & & & & & \\
\hline RDW $\leq 14.5 \%$ & 34.2 & & & & & & 1.0 & $<0.0001$ & 2.9 & 1.9 & 4.2 & & & & & \\
\hline $\begin{array}{l}\text { RDW } \leq 14.5 \% \text { and } W B C= \\
\text { normal }\end{array}$ & 31 & & & & & & & & & & & & $<0.0001$ & Reference & & \\
\hline $\begin{array}{l}\text { RDW }>14.5 \% \text { and } W B C= \\
\text { normal }\end{array}$ & 49 & & & & & & & & & & & 0.5 & 0.048 & 1.7 & 1.0 & 3.0 \\
\hline $\begin{array}{l}\text { RDW }>14.5 \% \text { and } \mathrm{WBC}= \\
\text { abnormal }\end{array}$ & 20 & & & & & & & & & & & 1.4 & $<0.0001$ & 4.1 & 2.6 & 6.5 \\
\hline Constant & & -2.084 & & & & & -1.96 & & & & & -1.97 & & & & \\
\hline $\begin{array}{l}\text { Hosmer and Lemeshow } \\
\text { Test }\end{array}$ & & & 0.543 & & & & & 0.344 & & & & & 0.565 & & & \\
\hline Area under curve & & & & 0.7376 & 0.691 & 0.781 & & & 0.743 & 0.699 & 0.788 & & & 0.755 & 0.711 & 0.799 \\
\hline
\end{tabular}

Elevated RDW levels on admission either alone or in combination of abnormal levels of white blood are associated with significant higher rates complicated hospitalization.

BUN, blood urea nitrogen; Coef, coefficient; RDW, red cell width distribution; WBC, white blood cells. 
Table 5 Univariate analysis of risk factors for detection of 90-day mortality

\begin{tabular}{|c|c|c|c|c|c|}
\hline Characteristic & & $\mathrm{N}_{\mathrm{T}}$ & 90-day mortality n (\%) & Odds ratio $(95 \% \mathrm{Cl})$ & $P$ value \\
\hline & & 637 & & & \\
\hline \multirow[t]{2}{*}{ Gender } & Male & 403 & $28(6.9)$ & $1.17(0.605-2.276)$ & 0.64 \\
\hline & Female & 234 & $14(6.0)$ & Reference & 1.000 \\
\hline \multirow[t]{4}{*}{ Age groups (years) } & $\leq 30$ & 126 & $5(4.0)$ & Reference & \\
\hline & $31-40$ & 136 & $4(2.9)$ & $0.73(0.192-2.794)$ & 0.65 \\
\hline & $41-50$ & 144 & $6(4.2)$ & $1.05(0.313-3.543)$ & 0.93 \\
\hline & $51-60$ & 231 & $27(11.7)$ & $3.2(1.202-8.537)$ & 0.02 \\
\hline Malignancy & & 60 & $11(18.3)$ & $3.95(1.873-8.349)$ & $<0.0001$ \\
\hline Prior neurologic damage & & 125 & $22(17.6)$ & $5.25(2.766-9.982)$ & $<0.0001$ \\
\hline Post chest radiation & & 31 & $17(9.9)$ & $3.56(1.716-7.400)$ & 0.001 \\
\hline Immune deficiency & & 156 & $19(12.2 \%)$ & $2.76(1.461-5.221)$ & 0.002 \\
\hline Corticosteroid therapy & & 76 & $10(13.2 \%)$ & $2.50(1.178-5.328)$ & 0.017 \\
\hline Nursing institution & & 52 & $10(19.2 \%)$ & $4.11(1.893-8.942)$ & $<0.0001$ \\
\hline $\mathrm{BUN}>10.7 \mathrm{mmol} / \mathrm{L}$ & & 65 & $9(13.8 \%)$ & $2.62(1.195-5.765)$ & 0.016 \\
\hline Hemoglobin $<110 \mathrm{~g} / \mathrm{L}$ & & 113 & $12(10.6 \%)$ & $2.02(0.999-4.100)$ & 0.050 \\
\hline WBC $<4$ or $>12 \times 10^{9} / \mathrm{L}$ & & 347 & $30(8.6 \%)$ & $2.19(1.101-4.365)$ & 0.025 \\
\hline RDW $>14.5 \%$ & & 218 & $27(12.4 \%)$ & $3.81(1.979-7.324)$ & $<0.0001$ \\
\hline
\end{tabular}

BUN, blood urea nitrogen; $\mathrm{Cl}$, confidence interval; $\mathrm{N}_{\mathrm{T}}$, all the patients that were included in the cohort; RDW, red cell width distribution; WBC, white blood cells.

The association of RDW and complicated hospitalization Ninety five $(55.6 \%)$ patients with complicated hospitalization had increased RDW as compared with $123(26 \%)$ patients with uncomplicated admissions $(P<0.0001)$.

Complicated hospitalization and mortality rates were significantly higher among patients with increased RDW regardless of the WBC count (Figure 1); the complicated hospitalization rate was $15.7 \%$ in patients with normal RDW and WBC and $20.3 \%$ in patients with only abnormal WBC count, as compared with $33.3 \%$ in patients with elevated RDW alone $(P=0.001)$ and $51.2 \%$ in patients with combined abnormal leukocyte count and increased RDW $(P<0.001)$. As shown in Figure 1, the 90day mortality was higher in patients with elevated RDW regardless of the WBC count; however, once again the combination of abnormal WBC and elevated RDW was significantly associated with the highest mortality rates.

In order to rule out the possibility that RDW effect on severe morbidity and mortality was unrelated to anemia, we compared complicated hospitalization in patients with hemoglobin (Hb) levels less than $110 \mathrm{~g} / \mathrm{L}$ and higher levels of $\mathrm{Hb}$. The two groups were examined in patients with normal and elevated RDW. As depicted in Figure 2, patients with normal RDW had no difference in severe morbidity or mortality regardless of $\mathrm{Hb}$ levels. On the other hand, elevated RDW was associated with a significant increase in both complicated hospitalization and 90-day mortality rates irrespective of $\mathrm{Hb}$ levels.

\section{Discussion}

This study shows that in young patients with CAP, elevated RDW levels on admission either alone or in combination with abnormal levels of WBC are associated with significant higher rates of mortality and complicated hospitalization. RDW level as a prognostic marker was unrelated to hemoglobin levels on admission.

RDW is a simple laboratory test used to evaluate variance in the size and form of red blood cells. It is an important marker in the differential diagnosis of anemia. However, RDW was shown to be a predictor of severe morbidity and mortality in several cardiac problems $[10-12,14]$. There is a large body of evidence showing that RDW is a strong predictor for an adverse outcome in these conditions, equivalent to other known markers, such as low ejection fraction, high New York Heart Association Functional Classification (NYHA) score and elevated serum B-Type Natriuretic peptide (BNP) levels [15]. Moreover, it was recently reported that RDW is a strong predictor of mortality in several other conditions such as obesity, malignancies, and chronic kidney disease [16]. Concordant with our findings, Wang et al. reported recently that a graded independent relation between higher RDW and adverse outcomes in ICU patients [17].

Several explanations were suggested to this surprising finding. Abnormal RDW usually suggests one or more chronic condition that accompanies significant heart failure, such as anemia or nutritional deficit. Another mechanism that was suggested is the release of cytokines in response to inflammatory stress. These cytokines block the activity of erythropoietin and cause production of ineffective red blood cell and elevated RDW $[18,19]$. Lippi et al found a correlation between 
Table 6 Results of multivariate analysis of risk factors for 90 -day mortality

\begin{tabular}{|c|c|c|c|c|c|c|c|c|c|c|c|c|c|c|c|c|}
\hline & \multirow{3}{*}{$\begin{array}{l}\% \text { from } \\
\text { total }\end{array}$} & \multicolumn{5}{|c|}{ Without RDW } & \multicolumn{5}{|c|}{ With RDW } & \multicolumn{5}{|c|}{ RDW and abnormal WBC } \\
\hline & & \multirow[t]{2}{*}{ Coef. } & \multirow[t]{2}{*}{$\begin{array}{l}P \\
\text { value }\end{array}$} & \multirow[t]{2}{*}{$\begin{array}{l}\text { Adjusted odds } \\
\text { ratio }\end{array}$} & \multicolumn{2}{|c|}{$\begin{array}{l}95 \% \\
\text { confidence } \\
\text { interval }\end{array}$} & \multirow[t]{2}{*}{ Coef. } & \multirow[t]{2}{*}{$\begin{array}{l}P \\
\text { value }\end{array}$} & \multirow[t]{2}{*}{$\begin{array}{l}\text { Adjusted odds } \\
\text { ratio }\end{array}$} & \multicolumn{2}{|c|}{$\begin{array}{l}95 \% \\
\text { confidence } \\
\text { interval }\end{array}$} & \multirow[t]{2}{*}{ Coef. } & \multirow[t]{2}{*}{$\begin{array}{l}P \\
\text { value }\end{array}$} & \multirow[t]{2}{*}{$\begin{array}{l}\text { Adjusted odds } \\
\text { ratio }\end{array}$} & \multicolumn{2}{|c|}{$\begin{array}{l}95 \% \\
\text { confidence } \\
\text { interval }\end{array}$} \\
\hline & & & & & Lower & Upper & & & & Lower & Upper & & & & Lower & Upper \\
\hline Age $\geq 51$ years & 36.3 & 1.2 & 0.001 & 3.3 & 1.7 & 6.5 & 1.1 & 0.001 & 3.1 & 1.6 & 6.2 & 1.0 & 0.003 & 2.8 & 1.4 & 5.6 \\
\hline Prior neurologic damage & 19.6 & 1.7 & $<0.0001$ & 5.3 & 2.7 & 10.2 & 1.6 & $<0.0001$ & 4.9 & 2.5 & 9.7 & 1.6 & $<0.0001$ & 5.0 & 2.6 & 10.0 \\
\hline Immunedeficiency & 24.5 & 1.1 & 0.001 & 3.1 & 1.6 & 6.2 & 0.8 & 0.001 & 3.1 & 1.6 & 6.2 & 0.9 & 0.012 & 2.5 & 1.2 & 5.0 \\
\hline RDW $\leq 14.5 \%$ & 34.2 & & & & & & 0.8 & & & & & & & & & \\
\hline $\begin{array}{l}\text { RDW } \leq 14.5 \% \text { and } \mathrm{WBC}= \\
\text { normal }\end{array}$ & 30.9 & & & & & & & & & & & & 0.016 & Reference & & \\
\hline $\begin{array}{l}\text { RDW }>14.5 \% \text { or } \mathrm{WBC}= \\
\text { normal }\end{array}$ & 49.5 & & & & & & & & & & & 0.9 & 0.128 & 2.4 & 0.8 & 7.3 \\
\hline $\begin{array}{l}\text { RDW }>14.5 \% \text { and } \mathrm{WBC}= \\
\text { abnormal }\end{array}$ & 19.6 & & & & & & & & & & & 1.6 & 0.007 & 4.8 & 1.5 & 15.3 \\
\hline Constant & & -4.187 & & & & & -4.453 & & & & & -4.937 & & & & \\
\hline $\begin{array}{l}\text { Hosmer and Lemeshow } \\
\text { Test }\end{array}$ & & & 0.310 & & & & & 0.363 & & & & & 0.708 & & & \\
\hline Area under curve & & & & 0.807 & 0.746 & 0868 & & & 0.822 & 0.766 & 0879 & & & 0.828 & 0.772 & 0885 \\
\hline
\end{tabular}

Elevated RDW either alone or in combination with abnormal WBC, proved to be significantly associated with increased mortality.

Coef, coefficient; RDW, red cell width distribution; WBC, white blood cells. 


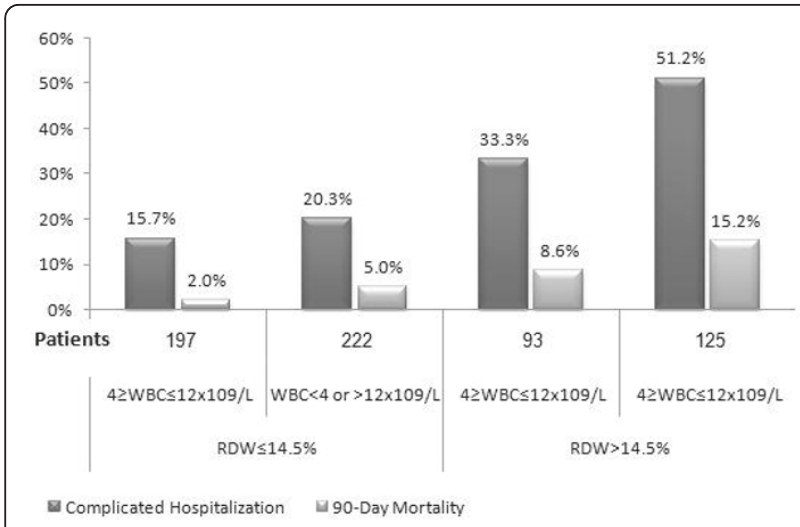

Figure 1 The association between the mortality rate and complicated with RDW and the different white blood cell groups. RDW, red cell width distribution; WBC, white blood cells.

high RDW and elevated indexes of inflammation, such as elevated erythrocyte sedimentation rate (ESR) and Creactive protein (CRP). This correlation was independent of concomitant diseases, and was demonstrated even when anemic patients were excluded from the statistical analysis [20].

Our data demonstrated that RDW is a valuable and sensitive marker for a high level of inflammatory activity in young patients with CAP, and it is independent of hemoglobin levels. The mechanism underlying the association between high levels of RDW and adverse outcome in patients hospitalized with pneumonia is unknown. RDW is elevated in conditions in which there is ineffective red cell production or increased destruction of red blood cell. RDW may indicate a severe inflammatory process, with impact on bone marrow function and iron metabolism. Another option is that RDW is an earlier marker of prognosis, and it may appear earlier in the complex process of anemia than low levels of hemoglobin. As noted before, high RDW

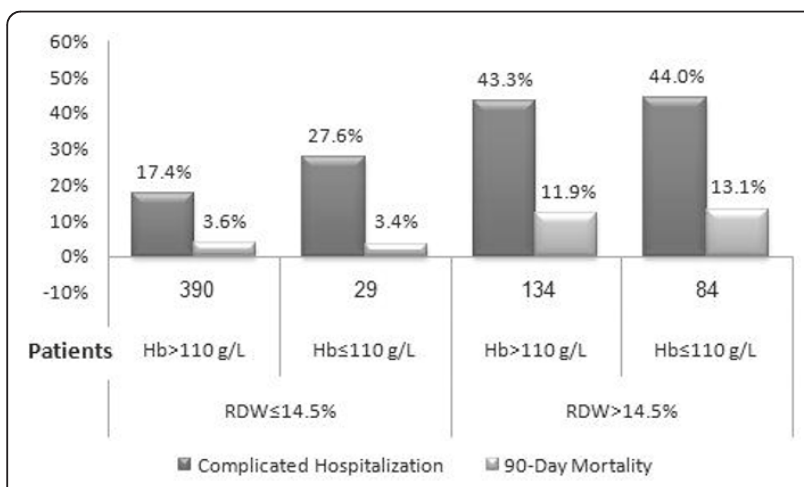

Figure 2 The association between the 90-day mortality rate and complicated with RDW and hemoglobin groups. $\mathrm{Hb}$, hemoglobin; RDW, red cell width distribution. levels may represent a culmination of multiple pathophysiologic processes occurring in acute inflammatory and infectious state.

Measuring RDW on admission is relatively simple and can be done during routine evaluation at the emergency room. Our data suggest that it may offer the physician another tool in the process of decision making whether to admit a patient diagnosed with CAP, in addition to the various scores that were developed in recent years for this purpose. Indeed, if RDW is proven to be a prognostic factor in older patients admitted with CAP, it might even be incorporated into such scores. In concordance with our data, several studies demonstrated the relation between mortality and elevated RDW in middle aged and older adults [21,22]. To our knowledge, our study is the first to show the poor prognostic effect of elevated RDW in young patients with CAP.

The major limitation of this study is its retrospective nature. In addition, our study examined RDW as a prognostic factor only in patients 60 years old and less. The majority of mortality and severe mortality in patients with CAP is in elderly patients, many of them have chronic hematologic and inflammatory co-morbidities. A larger cohort of this complex population is needed to clarify RDW as an independent risk factor in this population and to validate it prospectively including other inflammatory markers such as CRP, procalcitonin and IL-6. Notably, our study was planned to detect the association between elevated RDW and prognosis of CAP; however, we did not examine whether this observation is unique to CAP or could be demonstrated in other inflammatory and infectious states.

\section{Conclusions}

In young patients with CAP, elevated RDW levels are associated with significant higher rates of mortality and severe morbidity. RDW as a prognostic marker was unrelated with hemoglobin levels on admission.

\section{Key messages}

- Elevated RDW on admission is a recently described risk factor for adverse outcome in cardiac problems. - This study demonstrates that elevated RDW in young patients hospitalized with CAP is a significant risk factor for complicated hospitalization and inhospital mortality.

- Conceivably, measuring RDW in the emergency department might offer the clinician a simple yet powerful tool in the process of decision making whether to admit patients with CAP.

\section{Abbreviations}

AUC: area under curve; BNP: b-type natriuretic peptide; BUN: blood urea nitrogen; RDW: red cell distribution width; CAP: community acquired 
pneumonia; Cl: confidence interval; CRP: c-reactive protein; ESR: erythrocyte sedemintation rate; NYHA: New York Heart Association Functional Classification; OR: odds ratio; WBC: white blood cell.

\section{Acknowledgements}

This study was supported in part by the Rappaport Family Institute for Research in the Medical Sciences, Technion, Israel Institute of Technology, Haifa, Israel

\section{Author details}

'Department of Internal Medicine B, Rambam Health Care Campus, 1 Ha'aliya St. P.O.B. 9602 Bat Galim, Haifa 31096, Israel. ${ }^{2}$ Rappaport Faculty of Medicine, Technion-Israel Institute of Technology, Efron St. P.O.B. 9649 Bat Galim, Haifa 31096, Israel. ${ }^{3}$ Rappaport Family Institute for Research in the Medical Sciences, Technion, Efron St. P.O.B. 9649 Bat Galim, Haifa 31096, Israel.

\section{Authors' contributions}

EB was involved in the conception, defining the aims, designing the study, analysis of data, and writing and revising the final manuscript. ED was involved in designing the study, data acquisition and analysis, and writing and revising the manuscript. YK and YM assisted in data acquisition and manuscript revision. BFM assisted in data acquisition, manuscript revision, supplied some of the references concerning the RDW section and participated in revising the methods and results of this specific section. ZSA was involved in the conception, defining the aims, designing the study, analysis of data, preparing the figures and tables, writing, revising and submitting the manuscript and is the guarantor of the paper. All authors have read and approved the manuscript for publication.

\section{Competing interests}

The authors declare that they have no competing interests.

Received: 3 April 2011 Revised: 29 June 2011

Accepted: 11 August 2011 Published: 11 August 2011

\section{References}

1. Pinner RW, Teutsch SM, Simonsen L, Klug LA, Graber JM, Clarke MJ, Berkelman RL: Trends in infectious diseases mortality in the United States. JAMA 1996, 275:189-193.

2. Fry AM, Shay DK, Holman RC, Curns AT, Anderson L: Trends in hospitalizations for pneumonia among persons aged 65 years or older in the United States, 1988-2002. JAMA 2005, 294:2712-2719.

3. Garibaldi RA: Epidemiology of community-acquired respiratory tract infections in adults. Incidence, etiology, and impact. Am J Med 1985, 78:32-37.

4. Thomsen RW, Riis A, Norgaard M, Jacobsen J, Christensen S, McDonald CJ, Sorensen HT: Rising incidence and persistently high mortality of hospitalized pneumonia: a 10-year population-based study in Denmark. J Intern Med 2006, 259:410-417.

5. Renaud B, Labarere J, Coma E, Santin A, Hayon J, Gurgui M, Camus N, Roupie E, Hemery F, Herve J, Salloum M, Fine MJ, Brun-Buisson C: Risk stratification of early admission to the intensive care unit of patients with no major criteria of severe community-acquired pneumonia: development of an international prediction rule. Critical Care (London, England) 2009, 13:R54.

6. Fine MJ, Auble TE, Yealy DM, Hanusa BH, Weissfeld LA, Singer DE, Coley CM, Marrie TJ, Kapoor WN: A prediction rule to identify low-risk patients with community-acquired pneumonia. N Engl J Med 1997, 336:243-250.

7. Ghanem-Zoubi NO, Vardi M, Laor A, Weber G, Bitterman H: Assessment of disease-severity scoring systems for patients with sepsis in general internal medicine departments. Critical Care 15:R95.

8. Trotter CL, Stuart JM, George R, Miller E: Increasing hospital admissions for pneumonia, England. Emerg Infect Dis 2008, 14:727-733.

9. Bloos F, Marshall JC, Dellinger RP, Vincent JL, Gutierrez G, Rivers E, Balk RA, Laterre PF, Angus DC, Reinhart K, Brunkhorst FM: Multinational, observational study of procalcitonin in ICU patients with pneumonia requiring mechanical ventilation: a multicenter observational study. Critical Care 15:R88.
10. Felker GM, Allen LA, Pocock SJ, Shaw LK, McMurray JJ, Pfeffer MA, Swedberg K, Wang D, Yusuf S, Michelson EL, Granger CB, CHARM Investigators: Red cell distribution width as a novel prognostic marker in heart failure: data from the CHARM Program and the Duke Databank. $J$ Am Coll Cardiol 2007, 50:40-47.

11. Oh J, Kang SM, Hong N, Choi JW, Lee SH, Park S, Shin MJ, Jang Y, Chung N Relation between red cell distribution width with echocardiographic parameters in patients with acute heart failure. I Card Fail 2009, 15:517-522.

12. Hampole CV, Mehrotra AK, Thenappan T, Gomberg-Maitland M, Shah SJ: Usefulness of red cell distribution width as a prognostic marker in pulmonary hypertension. Am J Cardiol 2009, 104:868-872.

13. Ani C, Ovbiagele B: Elevated red blood cell distribution width predicts mortality in persons with known stroke. J Neurol Sci 2009, 277:103-108.

14. Jackson CE, Dalzell JR, Bezlyak V, Tsorlalis IK, Myles RC, Spooner R, Ford I, Petrie MC, Cobbe SM, McMurray JJ: Red cell distribution width has incremental prognostic value to B-type natriuretic peptide in acute heart failure. Eur J Heart Fail 2009, 11:1152-1154.

15. Pascual-Figal DA, Bonaque JC, Redondo B, Caro C, Manzano-Fernandez S, Sanchez-Mas J, Garrido IP, Valdes M: Red blood cell distribution width predicts long-term outcome regardless of anaemia status in acute heart failure patients. Eur J Heart Fail 2009, 11:840-846.

16. Patel KV, Semba RD, Ferrucci L, Newman AB, Fried LP, Wallace RB, Bandinelli S, Phillips CS, Yu B, Connelly S, Shlipak MG, Chaves PH, Launer LJ, Ershler WB, Harris TB, Longo DL, Guralnik JM: Red cell distribution width and mortality in older adults: a meta-analysis. Journals of Gerontology 2010, 65:258-265.

17. Wang F, Pan W, Pan S, Ge J, Wang S, Chen M: Red cell distribution width as a novel predictor of mortality in ICU patients. Annals Med 2011, 43:40-46.

18. Fukuta H, Ohte N, Mukai S, Saeki T, Asada K, Wakami K, Kimura G: Elevated plasma levels of B-type natriuretic Peptide but not C-reactive protein are associated with higher red cell distribution width in patients with coronary artery disease. Int Heart J 2009, 50:301-312.

19. Pierce CN, Larson DF: Inflammatory cytokine inhibition of erythropoiesis in patients implanted with a mechanical circulatory assist device. Perfusion 2005, 20:83-90.

20. Lippi G, Targher G, Montagnana M, Salvagno GL, Zoppini G, Guidi GC: Relation between red blood cell distribution width and inflammatory biomarkers in a large cohort of unselected outpatients. Arch Pathol Lab Med 2009, 133:628-632.

21. Patel KV, Ferrucci L, Ershler WB, Longo DL, Guralnik JM: Red blood cell distribution width and the risk of death in middle-aged and older adults. Arch Intern Med 2009, 169:515-523.

22. Perlstein TS, Weuve J, Pfeffer MA, Beckman JA: Red blood cell distribution width and mortality risk in a community-based prospective cohort. Arch Intern Med 2009, 169:588-594.

doi:10.1186/cc10355

Cite this article as: Braun et al.: Elevated red cell distribution width predicts poor outcome in young patients with community acquired pneumonia. Critical Care 2011 15:R194.

\section{Submit your next manuscript to BioMed Central and take full advantage of:}

- Convenient online submission

- Thorough peer review

- No space constraints or color figure charges

- Immediate publication on acceptance

- Inclusion in PubMed, CAS, Scopus and Google Scholar

- Research which is freely available for redistribution 